Article

\title{
Density of nocturnal mammals in a forest patch in Bangladesh
}

\author{
Hassan Al-Razi ${ }^{1, *}$, Sabit Hasan ${ }^{1}$, Tanvir Ahmed ${ }^{1}$ and Sabir Bin Muzaffar 2,* \\ 1 Faculty of Life and Earth Science, Department of Zoology, Jagannath University, Dhaka.; \\ chayan1999@yahoo.com (H.A.); khansabit4044@gmail.com (S.H.); shaikot2023jnu@gmail.com (T.A.) \\ 2 Department of Biology, United Arab Emirates University, Al Ain, United Arab Emirates; \\ s_muzaffar@uaeu.ac.ae \\ * Correspondence: chayan1999@yahoo.com (H.A.); s_muzaffar@uaeu.ac.ae (S.B.M.); Tel.: +971-3-713 6549 \\ (F.L.)
}

Simple Summary: Tropical forests represent complex associations of living species that have declined due to widespread deforestation. Forest patches exist in northeastern Bangladesh that still host a variety of species. We measured densities of nocturnal species of arboreal and ground dwelling mammals in Satchari, a small national park in northeastern Bangladesh. Highest densities were recorded in common palm civets (Paradoxurus hermaphrodites) and Bengal slow loris (Nycticebus bengalensis). Other species like the small Indian civets, large Indian civets and Indian mongoose were lower. Although many species were found to coexist, the conservation of species remains a major challenge due to high human density in surrounding areas. Strict implementation of conservation measures will be needed to ensure that these species survive in the long term.

\begin{abstract}
Tropical forests harbor complex communities that are linked together by biotic relationships. Asian forests in particular have lost many apex predators due to habitat loss. We studied a small forest patch in northeastern Bangladesh, Satchari National Park, to determine density and diversity of nocturnal mammals and evaluate their relationships. Transects were walked from February 2015 to July 2016 and density was estimated using distance sampling. Nine species of mammals ( 5 arboreal and 4 ground-dwelling) were encountered. Densities of the common palm civets, Paradoxurus hermaphrodites, Bengal slow loris, Nycticebus bengalensis, were the highest (19.48 and 15.03 individuals $/ \mathrm{km}^{2}$ ). Density of small Indian civets, large Indian civets and Indian mongoose were lower (2.31-5.55 individuals $/ \mathrm{km}^{2}$ ). Unexpectedly, a wide range of nocturnal mammals co-existed in this forest patch, in spite of fragmentation and severe disturbance. We did not find any significant association between any of the species studied, although this could be an artifact of low sample size. Conservation in Bangladesh remains a challenge due to high human population density. Thus, strict conservation measures are needed to permit the long-term survival of these species.
\end{abstract}

Keywords: Bengal slow loris; masked palm civet; common palm civet; conservation; forest canopy; density; Satchari National Park; tropical forest; Bangladesh.

\section{Introduction}

The global loss and degradation of forests and associated biodiversity have accelerated at an alarming pace in recent years, in spite of the fact that they have enormous environmental and economic value [1-4]. Tropical forests are the most ancient, diverse and ecologically complex of terrestrial communities $[3,5,6]$. Tropical forests support about two thirds of all known species and contain 65 percent of the world's 10,000 endangered species [7]. Deforestation is recognized as one of the most serious environmental and economic problems for many countries in the tropical and subtropical regions of the world $[3,4,8]$. Tropical areas, especially in Asia, are disappearing at a rate of over 80 million hectares of natural forests per year [4]. In the Indian subcontinent, forests have 
declined and many species have already become extirpated due to historical forestry practices (dating back to the 1920s) that focused on timber production, as well as due to ongoing deforestation, combined with massive human population growth [4,9-12].

The forest canopy is arguably the most species-rich and the most poorly understood habitats within forest ecosystems [13,14]. Canopies are commonly used by a variety of mammals, including marsupials, bats, rodents, carnivores, and primates [15]. Natural history literature provides evidence of apparent associations between a wide range of animals. Ecological associations may be defined as predictable patterns of abundance of species pairs or groups of species, despite the abundance of other similar species (with which their co-occurrences are not predictable)[16-18]. For example, Golden-headed Lion Tamarins (Leontopithecus chrysomelas) and a variety of canopy birds seem to be seen in association with each other and it is suggested that they increase mutual foraging efficiency [16]. Co-occurrence of species may indicate common habitat preferences, food abundance or predator avoidance [17-22], although in many cases, it is not at all clear if these co-occurrences represent true biotic interactions or if they are merely overlaps in distribution. Loss of apex predators due to habitat loss could result in trophic restructuring leading to significant changes in interactions amongst species in food webs [23]. In Asia, for example, loss of biodiversity has occurred over a 300-year period, starting from the period of British rule and modification of forests and subsequent rapid population increase in the previous century $[9,10,12]$. There has been a concomitant net loss of apex carnivore species such as leopards (Panthera pardus) and clouded leopards, (Neofelis nebulosi) [24,25]. Although the interactions between apex predators and arboreal mammals lower in the food web are not well characterized, antipredator defenses exist amongst prey species. For example, Wilcox et al. [26] reported on how two primate species (gibbon and langur) collaborated in mobbing a Sunda clouded leopard, $N$. diardi. This suggests that in the absence of apex predators, arboreal species are likely to change in behavior or numbers, resulting in changes in overall community structure in the remaining disturbed and semi-disturbed forests [23,27].

Although primates, in general, have received some attention, many studies focus on species feeding ecology and population size, rather than interspecies interactions [28,29]. In addition, most of the nocturnal canopy dwellers have remained unstudied in much of Asia [30-33]. Among nocturnal primates, for example, slow lorises play a pivotal role as pollinators in the tropical forests of South and Southeast Asia [34]. The Javan slow loris (Nycticebus javanicus) has been studied to some extent covering various aspects of feeding ecology, habitat use patterns and survival in human dominated landscapes [35-37]. One of the striking aspects of loris ecology is their ability to survive in heavily disturbed forests [38]. The Bengal slow loris, Nycticebus bengalensis is a small nocturnal primate that is heterogeneously distributed throughout their range. Abundance of the species is low and habitat alteration, destruction and capture for the pet trade are major factors influencing their declines. Little is known about the ecology, habitat characteristics and interspecies interactions of Bengal slow loris. Common palm civets (Paradoxurus hermaphrodites) and masked palm civets (Paguma larvata) typically share this habitat with slow lorises in Bangladesh, although there is no information on any niche segregation or overlap at the fine scale. Jennings and Veron [40] suggest that different species of civets and mongoose often occur in species pairs at the exclusion of other similar species pairs $[23,40]$.

The objectives of our study were (i) to determine the density of selected nocturnal mammals in a forest patch in Bangladesh; (ii) to characterize habitat use patterns in these mammals; and (iii) to assess the nature of interactions between some of these species in a protected, semi-evergreen deciduous forest in northeastern Bangladesh.

\section{Materials and Methods}

\subsection{Study site}

We selected Satchari National Park for this study (henceforth, Satchari). Satchari is a forest patch with an area of 242.91 ha that lies within the Raghunandan Hill Reserve Forest, under Paikpara Union, Chunarughat Upazilla, Habiganj District, under Sylhet region in northeastern Bangladesh (N 24'12.713' E 91⒋436') (Figure 1). It is $130 \mathrm{~km}$ from the capital city of Bangladesh, Dhaka. The 
southern part of the park is bordered by India; other adjacent areas are covered by tea estates, rubber, agar plantations and paddy fields. The area occupies the higher ridges of the northernmost extension of Dupitila, Tipam and Surma sedimentary rocks extending from the Chittagong Hill Tracts through Tripura State of India. Although this forest classically belongs to the evergreen type, the large-scale conversion of the indigenous forest cover to plantations has changed its forest type [41]. Currently, area old-growth forest 120.3 ha $(6.84 \%)$ Secondary 89.9 ha $(5.11 \%)$ Old plantation 63.9 ha $(3.63 \%)$ and 24.7 ha $(1.40 \%)$ Oil palm plantation [42]. The topography of the Satchari area is undulating with slopes and hillocks, ranging from 10 to $50 \mathrm{~m}$ in elevation. The climate is mainly tropical with high rainfall concentrated during the monsoon from June to September and generally 4 to 5 months of dry period. The total annual average rainfall is $4,162 \mathrm{~mm}$. A number of small, sandy-bedded streams drain the forest during the rainy season. The maximum and minimum temperature of the area is $32^{\circ} \mathrm{C}$ and $12^{\circ} \mathrm{C}$ respectively. The relative humidity fluctuates between $74 \%$ to $90 \%$ [43]. Biological diversity in Satchari is very rich [44,45]. About 167 plant species, 149 species of birds and 24 species of mammals have been recorded from the area [46].

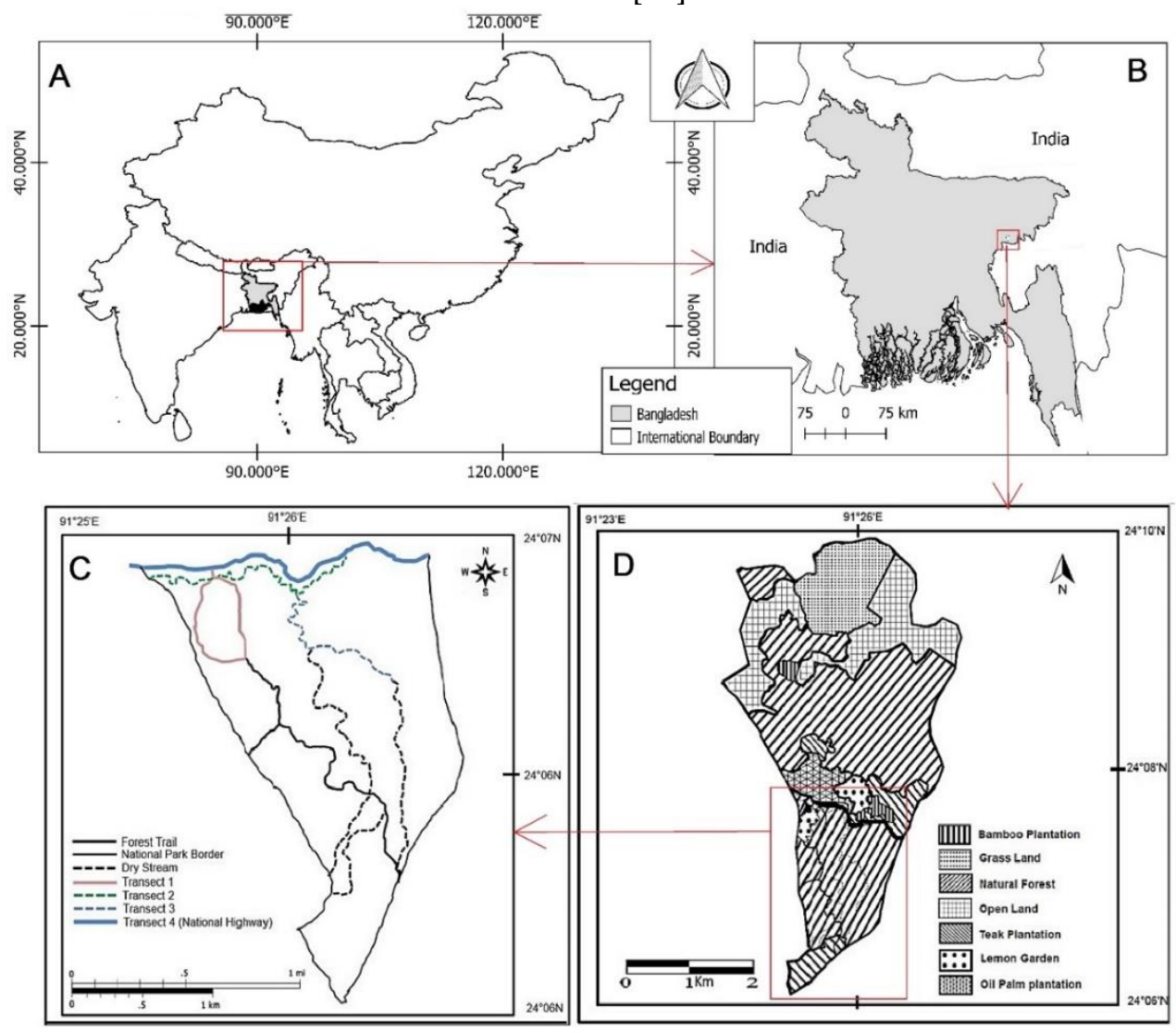

Figure 1. (a) and (b) Global position of Bangladesh denoting the Satchari National Park (c) Showing boundaries and relative location of transects in the Park; and (d) distribution of habitat types of the entire reserved forest.

\subsection{Encounter data}

A total of 4 transect lines were established and walked from 19 February 2015 to 24 July 2016 on 54 different nights. Transect lines were walked from $2300 \mathrm{~h}$ to $0400 \mathrm{~h}$ (mean $109 \pm 89$ minutes, $\mathrm{min}=$ 10 , max $=330$ ). The first transect (T1) was $1.64 \mathrm{~km}$ in length which consisted of a man-made trail that passed through lemon gardens, tea gardens, and mixed secondary forest. We designated this transect as 'garden'. The second and third transects (T2 and T3) were $1.4 \mathrm{~km}$ and $1 \mathrm{~km}$, respectively. These transects consisted of dry stream beds and passed through bamboo bush and secondary forest with varying tree density. We designated these as 'stream bed'. The fourth transect (T4) was $1.74 \mathrm{~km}$ 
running adjacent to a highway containing human habitation, secondary mixed forest, teak mixed forest, agar plantations, and palm oil plantations. We designated this transect as 'forest edge'. During each survey night, one of four transects (Figure 1) were walked at $1.5 \mathrm{~km} / \mathrm{h}$ and the canopy was searched using a 150 lumen light with a red filter $[47,48]$. Once a mammal was observed, its position was recorded using a GPS (Garmin eTrex 10), along with the tree species on which it was found. The perpendicular distance of each animal from the transect line was estimated [49,50]. Animal observation procedures conformed to the ethical guidelines of the Bangladesh Forest Department and Wildlife Act Bangladesh 2012.

\subsection{Estimation of encounter rate and density}

We used Distance 7.3 [51] to estimate density of all species observed based on distance sampling techniques that estimates species density from observed perpendicular distances of animals from a transect line [52]. Distance software explicitly models detection probability relative to the distance from the transect line [51]. The detection probabilities are then incorporated into conventional density estimation models and the best model is selected based on Akaike's Information Criteria (AIC). We also calculated encounter rates (number of observations of a given species per $\mathrm{km}$ of transect) [53], which serves as a convenient index for the comparison of inter-transect differences in relative abundance.

\subsection{Statistical analysis}

Encounter rates were compared between transects using One Way ANOVA, with bootstrap estimates of $p$ when normality assumptions were not fulfilled [54]. Briefly, Monte Carlo simulation methods were used to generate distribution free $p$ values from the data by resampling 2000 times with replacement [54]. We compared presence of the Bengal slow loris, common palm civets, masked palm civets, yellow-throated martens (Martes flavigula), large Indian civets (Viverra zibetha), small Indian civets (Viverricula indica), Indian mongooses (Herpestes auropunctatus), crab-eating mongoose (Herpestes urva) and particolored flying squirrels (Hylopetes alboniger) to compare for associations between these species. We used a Generalized Linear Mixed Model with presence of one species as the response variable and another species as an explanatory variable with transects as random effects. We did this for all species pairs to determine if associations were significant. All statistical analyses were done using Minitab 19.0 and the value $\alpha$ was set at 0.05 for all tests (Minitab Inc. 2020).

\section{Results}

Nine species of mammals (five arboreal and four ground-dwelling) were encountered. Encounters with slow loris, common palm civets and masked palm civets were most common. Particolored squirrels, yellow-throated martens and crab eating mongooses could not be estimated adequately due to insufficient observations and their densities are not provided. Density estimates generated by half normal models were selected in all cases as they had the greatest AIC support [51] Densities of the slow loris and common palm civets were the highest (15.03 and 19.48 individuals $/ \mathrm{km} 2$, respectively Table 1). Encounter rates (individuals $/ \mathrm{km}$ ) were also the highest for these species $(0.84 \pm 0.04$ and $0.59 \pm 0.03$ individuals $/ \mathrm{km}$, respectively, Table 1$)$. Density and encounter rates of small Indian civets, large Indian civets and Indian mongoose were low (densities of 2.31-5.55 individuals $/ \mathrm{km} 2$ and encounter rates of $0.05 \pm 0.02-0.11 \pm 0.03$ individuals $/ \mathrm{km}$, Table 1). 
Table 1. Encounter rates and densities of nocturnal mammals in Satchari National Park

\begin{tabular}{|c|c|c|c|c|c|c|c|c|}
\hline Species & $\begin{array}{l}\text { Number } \\
\text { of } \\
\text { paramet } \\
\text { ers }\end{array}$ & AIC & $\begin{array}{l}\text { Estimate } \\
\text { strip } \\
\text { width } \\
\text { (m) }\end{array}$ & $\begin{array}{l}\text { Densit } \\
\mathrm{y} \\
\left(\mathrm{n} / \mathrm{km}^{2}\right)\end{array}$ & $\begin{array}{l}\text { Lower } \\
\text { confidence } \\
\text { level }\end{array}$ & $\begin{array}{l}\text { Upper } \\
\text { confidenc } \\
\text { e level }\end{array}$ & $\begin{array}{l}\text { Coeffici } \\
\text { ent of } \\
\text { Varianc } \\
\text { e }\end{array}$ & $\begin{array}{l}\text { Encounter } \\
\text { rate } \\
(\mathrm{n} / \mathrm{km})\end{array}$ \\
\hline Slow Loris & 3 & 682.73 & 21.14 & 15.03 & 11.09 & 20.36 & 0.15 & $0.84 \pm 0.04$ \\
\hline $\begin{array}{l}\text { Common } \\
\text { Palm Civet }\end{array}$ & 1 & 397.64 & 12.95 & 19.48 & 15.84 & 23.95 & 0.11 & $0.59 \pm 0.03$ \\
\hline $\begin{array}{l}\text { Masked } \\
\text { Palm Civet }\end{array}$ & 1 & 149.63 & 14.69 & 6.89 & 3.98 & 11.92 & 0.28 & $0.22 \pm 0.04$ \\
\hline $\begin{array}{l}\text { Large Indian } \\
\text { Civet }\end{array}$ & 1 & 66.47 & 10.00 & 5.55 & 2.99 & 10.31 & 0.32 & $0.11 \pm 0.03$ \\
\hline $\begin{array}{l}\text { Small Indian } \\
\text { Civet }\end{array}$ & 1 & 71.30 & 18.64 & 2.31 & 1.05 & 5.11 & 0.41 & $0.08 \pm 0.02$ \\
\hline $\begin{array}{l}\text { Indian } \\
\text { Mongoose }\end{array}$ & 1 & 26.95 & 8.00 & 3.03 & 1.11 & 8.28 & 0.52 & $0.05 \pm 0.02$ \\
\hline
\end{tabular}

Most species did not show significant differences in encounter rates in different transects. Encounter rates of common palm civet showed significant differences between transects (One Way ANOVA, $F=4.73, p=0.004$, Figure 2). Common palm civets and masked palm civet occurred in significantly higher density in one of the stream bed transects compared to all other, although the difference in masked palm civets were not significant. Large Indian civets were absent from the stream bed transect but there was no difference in their densities in the remaining transects. Generalized Linear Mixed Model analysis did not show any significant associations between any of the species. 


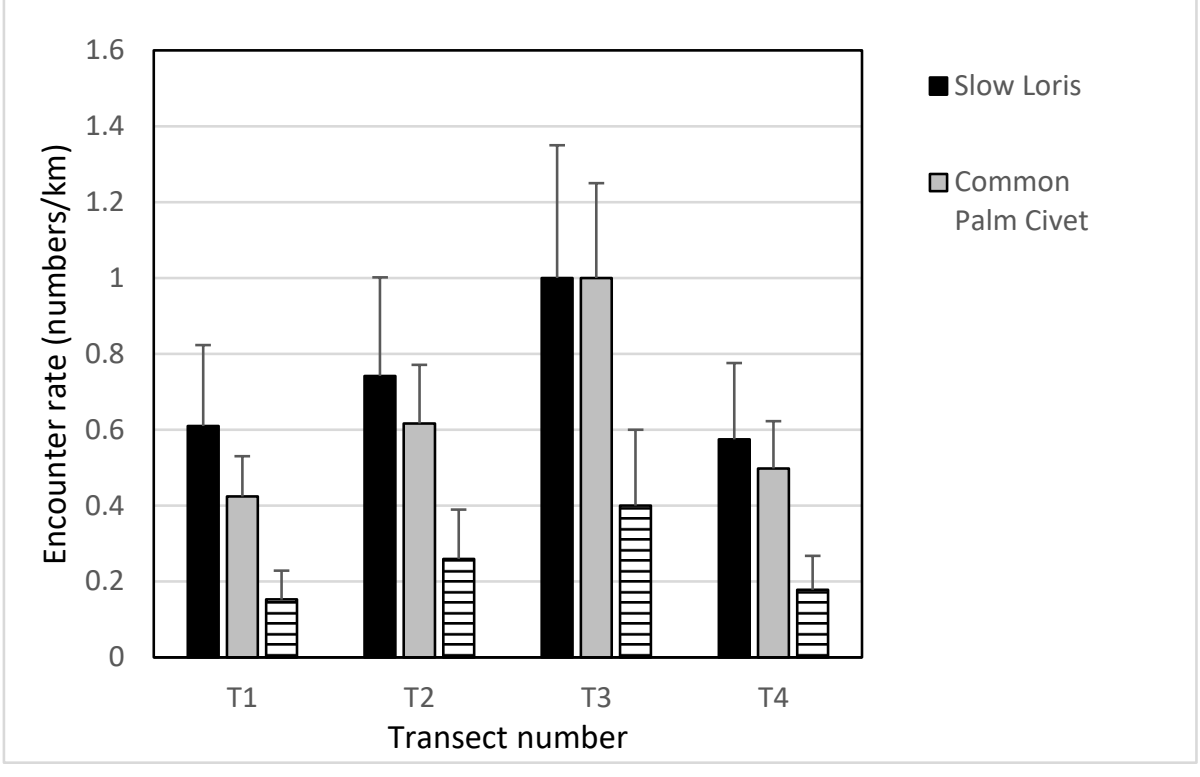

Figure 2. Comparison of the encounter rate of mammals in the different transects. T1= transect 1 : garden; $\mathrm{T} 2$ and $\mathrm{T} 3=$ transects 2 and 3, dry river beds; $\mathrm{T} 4=$ transect 4 : forest edge.

\section{Discussion}

A diverse community of nocturnal mammals were recorded in this forest patch of our study. Density estimates for slow lorises in our study were considerably higher than other studies. For example, Pliosungneon et al. [55] reported density estimates ranging from 1.4-4.26 lorises $/ \mathrm{km}^{2}$ (compared to 15.03 lorises $/ \mathrm{km}^{2}$ in our study) that seemingly varied with habitat type, with highest densities recorded in older plantations, although the differences were not significant. Encounter rates reported in other studies (such as $0.10-0.13 / \mathrm{km}$, [53]) were also lower than our encounter rates for slow loris of $0.84 / \mathrm{km}$. The higher relative abundance of slow lorises in older plantations [55] was attributed to presence of Bauhinia spp. (lianas) and the absence of competitors, suggesting that disturbed sites could be preferentially chosen. In our study, slow lorises were generally abundant in the mixed forest habitat and density was lower in the garden and forest edge transects. This could still be consistent with Pliosungneon et al. [55] since the entire forest of Satchari is a highly disturbed plantation with many of the varied tree species planted in cycles in the 1920s, 1930s and 1940s. The stream bed transects were within areas that could be considered old plantations where higher density of slow lorises occur. On the other hand, garden and highway transects were more disturbed compared to stream bed transects, causing lower densities to occur. We recognize that we had very few transects that were sampled and variable encounter rates could have been an artifact of small sample sizes. We suspect that sampling in a larger number of transects over larger areas of forest would likely yield different encounter rates and therefore density estimates. Nevertheless, we speculate that slow lorises thrive in disturbed forests but there is a threshold of disturbance beyond which slow loris densities decline.

Species of the family Viverridae are among the most widespread and diverse components of Asian tropical communities [56]. Although they are primarily carnivorous, some species, particularly those of the subfamilies Viverrinae and Paradoxurinae, feed extensively upon fruits [57]. Apart from some field observations and captive studies [58], there is little detailed ecological information on civets. In our study, common palm civets had higher densities compared to those reported in the 
literature [59,60]. For example, Iseborn et al. [60] reported encounter rates of 0.35-0.39/km in two different national parks in Cambodia compared to $0.59 / \mathrm{km}$ in our study. It may be mentioned that the forest type in their study was considerably different with higher tree density, tree diversity, forest type, diversity of mammals and overall area totaling to more than $3300 \mathrm{~km}^{2}$ (compared to our $2.4 \mathrm{~km}^{2}$ study site). Nakashima et al. [59] showed that common palm civets in human-altered landscapes in Malaysia reduced home range size near palm oil plantations and selectively used palm trees with dense leaves within plantations for day-beds (diurnal resting areas). Although Nakashima et al. [59] did not report density or encounter rates, the reduction in home range size and the larger proportion of individuals observed near plantations implied that their density in these areas was higher and that they had the ability to utilize highly altered and disturbed habitats. In our study, common palm civets were also relatively more abundant in the stream bed transects running through mixed forests, consistent with the suggestion that disturbance was high in these places, but below a threshold, allowing the species to maintain high densities. In comparison, the garden and forest edge transects were probably more disturbed compared to the mixed forest transects, supporting lower densities of the species. In comparison, masked palm civet densities were considerably lower in our study and comparable to the few studies that estimated density in highly disturbed forest patches [61]. We speculate that masked palm civets are unable to increase in numbers under high levels of disturbance, unlike common palm civets. Civets, in general, are frugivorous carnivores and are regarded as one of the most important seed dispersal agents in the rainforests of Southeast Asia [62-67]. Thus, higher densities of the common palm civet are indicative of the relatively high diversity and abundance of fruiting trees in our study.

Among the ground-dwelling carnivores, the large Indian civet and the Indian mongoose were both similar in density. Large Indian civets are regarded as relatively abundant throughout South and Southeast Asia $[68,69]$ although we could not find any estimates of density in the published literature. Datta et al. [68] suggested that the species was common in Namdapha National Park in northeastern India, based on higher number of captures in camera traps. Since they estimated relative abundance indices [68], their data are not comparable with ours. However, broad generalizations on distribution could be inferred from their study. Large Indian civets tend to be present in greater numbers in mixed forests rather than in sal (Shorea robusta) dominated forests [69]. The low density of large Indian civets in our study suggests that possibly the disturbance in our study site could be too high for this species. The higher density in the highway transect is also perplexing since the opposite was expected. More work is needed to better understand the patterns of distribution and abundance of this species in the region.

The Indian mongoose appears to be suppressed in numbers in our study. Evidence from areas where the Indian mongoose has been introduced suggests that they could increase rapidly in numbers and achieve densities of 33-500 individuals $/ \mathrm{km}^{2}$ in the absence of competitive pressure [e.g., $70,71]$. However, in our study, with an abundance of mesopredators of similar or larger size, or possible dietary or niche overlap, mongoose populations are possibly unable to attain high densities. We regard this as an indication of a mixed community of ground dwelling small mammals without any species dominating over others. It is also possible that our density estimates were low because most Indian mongoose are diurnal and our density estimates were a reflection of a part of the population. 
We recognize that our study site was small and the general observations and estimates need to be validated from more areas within Bangladesh, especially those with larger forest cover and area. We realize that density estimates in small areas could be biased due to repeat counts of the same animals. However, in our study, we repeatedly walked the same transects at different times of the year to better assess temporal variability in density data to derive a relatively robust estimate of density for each species. Estimates of animals encountered with higher frequency were likely to be more accurate compared to those encountered less frequently [49,50]. Thus, density estimates of species encountered in low frequency should be treated with caution. Nevertheless, given the relatively small size and the ease with which most species were encountered, we interpret the low densities of some species as authentic. Generally, most remaining forest fragments in Bangladesh suffer from similar or higher levels of disturbance compared to our study site $[9,10,12]$. Illegal logging and forest conversion continue to remain as major threats to biodiversity in most forested areas in Bangladesh. Protected area management remains rudimentary and inconsistent with ecosystem approaches to conservation [11]. In spite of such disturbance, we suggest that mesopredator release may have occurred in this and many other forests in Bangladesh, resulting in diverse communities in these remaining forest patches. Although more detailed studies are in order, as a precautionary approach, a total cessation of activities that reduce biodiversity loss (illegal logging, poaching or land conversion) is urgently needed to allow the last remaining canopy species to survive.

\section{Conclusions}

We conclude that arboreal mammals such as the common palm civet and Bengal slow loris still exist in this small forest patch in densities comparable to larger forests. Other species such as masked palm civet, and the ground dwelling small Indian civet and large Indian civet exist in lower densities. The entire forest is disturbed and stricter measures are needed to permit long-term survival of these species.

Author Contributions: HA and SBM planned and designed the study and wrote the manuscript. Data was managed and analyzed by HA and SBM. HA, SH and TA conducted the field work and collected data.

Funding: This research received no external funding.

Acknowledgments: We are thank K.A.I. Nekaris for her valuable advice during field work. We thank the Forest Department of Bangladesh for permission to carry out the study. The authors are grateful to Professor Abdul Alim, Chairman, Department of Zoology, Jagannath University, for his support. We are thankful to M. Anisur Rahman (beat officer) and Mahmud Hussain (range officer) of Satchari National Park for their support during the study. We are thankful to Marjan Maria for her support in manuscript preparation.

Conflicts of Interest: The authors declare no conflict of interest.

\section{References}

1. Kaimowitz, D.; Angelsen, A. Economic models of tropical deforestation: A review. Bogor, Indonesia: CIFOR, 1998.

2. FAO. Global Forest Resources Assessment 2005. FAO Forestry Paper. UN Food and Agriculture Organization, Rome, 2006.

3. FAO. Global forest resources assessment 2010. Food and Agriculture Organization of the United Nations, Rome, 2010.

4. FAO. Global Forest Resources Assessment 2015. FAO Forestry Paper No. 1. UN Food and Agriculture Organization, Rome, 2015.

5. Myers, N. The Primary Source: Tropical Forests and Our Future. New York. USA: W.W. Norton, 1984.

6. Wilson, E. O. Threats to Biodiversity. Sci. Am. 1989, 261, 108-116. 
7. Myers, N.; Mittermeier, R. A.; Mittermeier, C. G.; da Fonseca, G. A. B.; Kents, J. Biodiversity hotspots for conservation priorities. Nature. 2000, 403, 853-858.

8. Hare, M. A.; Lantagne, D. O.; Murphy, P. G.; Checo, H. Structure and tree species composition in a subtropical dry forest in the Dominican Republic: comparison with a dry forest in Puerto Rico. Trop Ecol. 1997, 38, 1-17.

9. Kabir, D. S.; Muzaffar, S. B. The review of the present state of protected areas of Bangladesh. In: M. F. Ahmed, S. A. Tanveer, \& A. B. M. Badruzzaman (Eds). Bangladesh environment 2002. Dhaka, Bangladesh: Bangladesh Poribesh Rokha Andolon (BAPA). 2002, 389-403.

10. Kibria, M. G.; Rahman, S. A.; Imtiaj, A.; Sunderland, T. Extent and consequences of tropical forest degradation: successive policy options for Bangladesh. J. Agric. Sci. Technol. 2011, 1, 29-37.

11. Muzaffar, S. B.; Islam, M. A.; Kabir, D. S.; Khan, M. H.; Ahmed, F.U.; Chowdhury, G. W.; Aziz, M. A.; Chakma, S.; Jahan, I. The endangered forests of Bangladesh: why the process of implementation of the Convention on Biological Diversity is not working. Biodivers Conserv. 2011, 20, 1587-1601.

12. Islam, K.; Sato, N. Deforestation, Land Conversion and Illegal Logging in Bangladesh: The Case of the Sal (Shorea robusta) Forests. iForest-Biogeosciences and Forestry. 2012, 5, 171-178.

13. Erwin, T. L. Tropical forest canopies, the last biotic frontier. Bulletin of the Entomological Society of America. 1983, 29, 14-19.

14. Nadkarni, N. M. Diversity of species and interactions in the upper tree canopy of forest ecosystems. Am. Zool. 1994, 34, 321-330.

15. Nowak, R. M. Walker's Mammals of the World. 5th ed. Baltimore, Maryland: Johns Hopkins University Press. 1991, 2, 1712.

16. Hankerson, S. J.; Dietz, J.; Raboy, B. E. Associations between golden-headed lion tamarins and the bird community in the Atlantic Forest of southern Bahia. Int. J. Primatol. 2006, 27(2), 487-495.

17. Choudhury, K. C. R. Behaviour of chital Axis axis (Erxleben). J. Bombay Nat. Hist. Soc. 1966, 63, 747.

18. Boinski, S.; Scott, P. E. Association of birds with monkeys in Costa Rica. Biotropica. 1988, 20, 136-143.

19. Ferrari, S. F.; Lopes-Ferrari, M. A. A re-evaluation of the social organisation of the Callitrichidae, with reference to the ecological differences between genera. Folia Primatol. 1989, 52, 132-147.

20. Egler, S. G. Double-toothed kites following tamarins. Wilson Bull. 1991, 103, 510-512.

21. Heymann, E. W. Associations of tamarins (Saguinus mystax and Saguinus fuscicollis) and double-toothed kites (Harpagus bidentatus) in Peruvian Amazonia. Folia Primatol. 1992, 59, 51-55.

22. Booth-Binczik, S. D.; Binczik, G. A.; Labisky, R. F. A possible foraging association between White Hawks and White-nosed Coatis. Wilson Bull. 2004, 116, 101-103.

23. Prugh, L. R.; Stoner, C. J.; Epps, C. W.; Bean, W. T. W.; Ripple, J.; Laliberte, A. S.; Brashares, J. S. The rise of the mesopredator. BioScience. 2009, 59, 779-791.

24. Grassman, L.; Lynam, A.; Mohamad, S.; Duckworth, J. W.; Bora, J.; Wilcox, D.; Ghimirey, Y.; Reza, A.; Rahman, H. Neofelis nebulosa. The IUCN Red List of Threatened Species 2016: e. T14519A97215090. Retrieved from http://dx.doi.org/10.2305/IUCN.UK.2016-1.RLTS.T14519A97215090.en.

25. Stein, A. B.; Athreya, V.; Gerngross, P.; Balme, G.; Henschel, P.; Karanth, U.; Miquelle, D.; Rostro-Garcia, S.; Kamler, J. F.; Laguardia, A.; Khorozyan, I.; Ghoddousi, A. Panthera pardus. The IUCN Red List of Threatened Species 2016: e. T15954A102421779. Retrieved from http://dx.doi.org/10.2305/IUCN.UK.20161.RLTS.T15954A50659089.en.

26. Wilcox, C. H.; Supiansyah, A.; Azis, J.; Rahman, Z.; Cheyne, S. M. Predator Mobbing and Interspecies Cooperation: An interaction between gibbons, langurs and a clouded leopard. Asian Primates Journal. 2016, 6, 20-26.

27. Soulé, M. E.; Bolger, D. T.; Alberts, A. C.; Wright, J.; Sorice, M.; Hill, S. Reconstructed dynamics of rapid extinctions of chaparral-requiring birds in urban habitat islands. Conserv. Biol. 1988, 2, 75-91.

28. Muzaffar, S. B.; Islam, M. A.; Feeroz, M. M.; Kabir, M.; Begum, S.; Mahmud, S.; Chakma, S. Habitat characteristics of the endangered Hoolock Gibbons (Hoolock hoolock) of Bangladesh: the role tree species richness. Biotropica. 2007, 39, 539-545.

29. Islam, M. A.; Feeroz, M. M.; Muzaffar, S. B.; Kabir, M. M.; Begum, S. Conservation of the hoolock gibbons (Hoolock hoolock) of Bangladesh: Population estimates, habitat suitability and management options Technical Report. U.S. Fish and Wildlife Service. 2006.

30. Nekaris, K. A. I. Activity budget and positional behavior of the Mysore slender loris (Loris tardigradus lydekkerianus): Implications for slow climbing locomotion. Folia Primatol. 2001. 72, 228-241

31. Nekaris, K. A. I.; Shepherd, C. R.; Starr, C. R.; Nijman, V. Exploring cultural drivers for wildlife trade via an ethnoprimatological approach: a case study of slender and slow lorises (Loris and Nycticebus) in South and Southeast Asia. Am. J. Primatol. 2010. 72, 877-886 
32. Nekaris, K. A. I.; Moore, R. S.; Rode, E. J.; Fry, B. G. Mad, bad and dangerous to know: the biochemistry, ecology and evolution of slow loris venom. J. venom. anim. toxins incl. trop. dis. 2013, 19, 21.

33. Nekaris, K. A. I.; Starr, C. R. Conservation and ecology of the neglected slow loris: priorities and prospects. Endanger Species Res. 2015, 28, 87-95.

34. Starr, C.; Nekaris, K. A. I. Obligate exudativory characterizes the diet of the pygmy slow loris Nyctiebus pygmaeus. Am. J. Primatol. 2013, 75, 1054-1061.

35. Nekaris, K. A. I. Extreme primates: Ecology and evolution of Asian lorises. Evol. Anthropol. 2014, 23, 177-187.

36. Rode-Margono, E. J.; Nijman, V.; Wirdateti,; Nekaris, K. A. I. Ethology of the Critically Endangered Javan slow loris Nycticebus javanicus É. Geoffroy Saint-Hilaire in West Java. Asian Primate Journal. 2014, 4, 27-41.

37. Voskamp, A.; Rode, E.; Coudrat, C.; Wilson, R.; Nekaris, K. A. I. Modelling the habitat use and distribution of the threatened Javan slow loris Nycticebus javanicus. Endanger Species Res. 2014, 23, $277-$ 286.

38. Nekaris, K. A. I.; Poindexter, S. A.; Reinhardt, K. D.; Wirdateti, W.; Sigaud, M.; Cabana, F.; Nijman, V. Coexistence between Javan Slow Lorises (Nycticebus javanicus) and Humans in a Dynamic Agroforestry Landscape in West Java, Indonesia. Int. J. Primatol. 2017, 38, 303-320.

39. Streicher, U.; Singh, M.; Timmins, R. J.; Brockelman, W. Nycticebus bengalensis. The IUCN Red List of Threatened Species 2008. e. T39758A10263081. Retrieved from http://dx.doi.org/10.2305/IUCN.UK.2008.RLTS. T39758A10263081.en.

40. Jennings, A. P.; Veron, G. Predicted distributions and ecological niches of 8 civet and mongoose species in Southeast Asia. J. Mammal. 2011, 92, 316-327.

41. Choudhury, J. K.; Biswas, S. R.; Islam, M.; Rahman, S. O.; Uddin, S. N. Biodiversity of Shatchari Reserved Forest, Habiganj. Dhaka, Bangladesh: IUCN Bangladesh Country Office. 2004.

42. Mukul, S. A.; Sohel, M. S. I.; Herbohn, J.; Inostroza, L.; König, H. Integrating ecosystem services supply potential from future land-use scenarios in protected area management: A Bangladesh case study. Ecosyst. Serv. 2017, 26, 355-364.

43. Mollah, A. R.; Kundu, D. K.; Rahman, M. M. Site-level field appraisal for protected area comanagement: Satchari Reserve Forest. Dhaka, Bangladesh: Nature Conservation Management (NACOM). 2004.

44. Al-Razi, H.; Maria, M.; Hasan, S.; Muzaffar, S. B. First record of Raorchestes longchuanensis Yang and Li, 1978 (Anura: Rhacophoridae) from northeastern Bangladesh suggests wide habitat tolerance. Amphibian \& Reptile Conservation. 2020, 14(1), 119-131 (e225).

45. Al-Razi, H.; Maria, M.; Muzaffar, S. B. Mortality of primates due to roads and power lines in two forest patches in Bangladesh. Zoologia. 2019, 36, 1-6. https://doi.org/10.3897/zoologia.36.e33540

46. Nishorgo Supported Project. Nishorgho Project Proforma. Dhaka, Bangladesh. 2005.

47. Nekaris, K. A. I. Spacing system of the Mysore slender loris (Loris lydekkerianus lydekkerianus). Am. J. Phys. Anthropol. 2003, 121, 86-96.

48. Al-Razi, H.; Hasan, S.; Ahmed, T.; Muzaffar, S. B. Home Range, Activity Budgets and Habitat Use in the Bengal Slow Loris (Nycticebus bengalensis) in Bangladesh. In Evolution, Ecology and Conservation of Lorises and Pottos (Cambridge Studies in Biological and Evolutionary Anthropology); Nekaris, K., Burrows, A., Eds.; Cambridge University Press, Cambridge, UK, 2020, pp. 193-203. doi:10.1017/9781108676526.019

49. Burnham, K. P.; Anderson, D. R.; Laake, J. L. Estimation of density from line transect sampling of biological populations. Wildlife Monogr. 1980, 72, 1-202.

50. Harris, R. B.; Burnham, K. P. On estimating wildlife densities from line transect data. Acta Zoologica Sinica. 2002, 48, 812-818.

51. Thomas, L.; Buckland, S. T.; Rexstad, E. A.; Laake, J. L.; Strindberg, S.; Hedley, S. L.; Bishop, J. R. B.; Marques, T. A.; Burnham, K. P. Distance software: design and analysis of distance sampling surveys for estimating population size. J. Appl. Ecol. 2008, 47(1), 5-14.

52. Buckland, S. T.; Anderson, D. R.; Burnham, K. P.; Laake, J. L.; Borchers, D. L.; Thomas, L. J. Advanced Distance Sampling. Oxford University Press, Oxford, UK, 2004, pp. 1-434.

53. Nekaris, K. A. I.; Blackham, G. V.; Nijman, V. Conservation implications of low encounter rates of five nocturnal primate species (Nycticebus spp.) in Asia. Biodivers Conserv. 2008, 17, 733-747.

54. Sokal, R. R.; Rohlf, F. J. Biometry: the principles and practice of statistics in biological research. 4th edition. New York, USA: W. H. Freeman and Co. 2012, 915.

55. Pliosungneon, M.; Gale, G.; Savini, T. Density and microhabitat use of Bengal Slow Loris in primary forest and non-native plantation forest. Am. J. Primatol. 2010, 72, 1108-1117. 
56. Veron. G.; Patou. M.L.; Tóth, M.; Goonatilake, M.; Jennings, A. P. How many species of Paradoxurus civets are there? New insights from India and Sri Lanka. J. Zool. Syst. Evol. Res. 2014, 53, 161-174.

57. Ewer, R. F. The carnivores. Ithaca, New York, USA: Cornell University Press. 1973, 500.

58. Wemmer, C.; Watling, D. Ecology and status of the Sulawesi Palm Civet (Macrogalidia musschenbroekii). Biol. Conserv. 1986, 351, 1-17.

59. Nakashima, Y.; Nakabayashi, M.; Sukor, J. A. Space use, habitat selection, and day-beds of the Common Palm Civet (Paradoxurus hermaphroditus) in human-modified habitats in Sabah. Borneo. Journal of Mammalogy. 2013, 94, 1169-1178.

60. Iseborn, T. L.; Rogers, D.; Rawson, B.; Nekaris, K. A. I. Sightings of common palm civets Paradoxurus hermaphroditus and of other civet species at Phnom Samkos Wildlife Sanctuary and Veun Sai-Siem Pang Conservation Area, Cambodia. Small Carnivore Conservation. 2012, 46, $26-29$.

61. Heydon, M.; Bulloh, P. The impact of selective logging on sympatric civet species in Borneo. Oryx. 1996, 30, 31-36.

62. Corlett, R. T. Frugivory and seed dispersal by vertebrates in the Oriental (Indomalayan) Region. Biol. Rev. 1998, 73, 413-448.

63. Joshi, A. R.; Smith, J. L. D.; Cuthbert, F. J. Influence of food distribution and predation pressure on spacing behavior in palm civets. J. Mammal. 1995, 76, 1205-1212.

64. Mudappa, D. Ecology of the brown palm civet Paradoxurus jerdoni in the tropical rainforests of the Western Ghats, India. PhD thesis, Bharathiar University, Coimbatore, India. 2001.

65. Rabinowitz, A. R. Behaviour and movements of sympatric civet species in Huai Kha Khaeng Wildlife Sanctuary, Thailand. J. Zool. 1991, 223, 281-298.

66. Stoner, K. E.; Riba-Hernandez, P.; Vulinec, K.; Lambert, J. E. The role of mammals in creating and modifying seed shadows in tropical forests and some possible consequences of their elimination. Biotropica. 2007, 39, 316-327.

67. Zhou, Y.; Zhang, J.; Slade, E.; Zhang, L.; Palomares, F.; Chen, J.; Wang, X. Dietary shifts in relation to fruit availability among masked palm civets (Paguma larvata) in central China. J. Mammal. 2008, 89, 435447.

68. Datta, A.; Naniwadekar, R.; Anand, M. O. Occurrence and conservation status of small carnivores in two protected areas in Arunachal Pradesh, north-east India. Small Carnivore Conservation. 2008, 39, 110 .

69. Bista, A.; Chanchani, P.; Warrier, R.; Mann, R.; Gupta, M.; Vattakavan, J. Detection of Large Indian Civet Viverra zibetha in camera-trap surveys in and around Dudhwa National Park in the Terai Region of North India. Small Carnivore Conservation. 2012, 47, 54-57.

70. Horst, G. R.; Hoagland, D. B.; Kilpatrick C. W. The mongoose in the West Indies: the biogeography and population biology of an introduced species. In: C. A. Woods, \& F. E. Sergile (Eds), Biogeography of the West Indies: patterns and perspectives, Boca Raton, Florida, USA: CRC Press. 2001, 409-424.

71. Johnson, S. R.; Berentsen, A. R.; Ellis, C.; Davis, A.; VerCauteren, K. C. Estimates of small Indian mongoose densities: implications for rabies management. J. Wildl. Manage. 2016, 80, 37-47. 